Mast, M.R., Walraven, L., Hoekstra, T., Jansen, A.P.D., Heijden, A.A.W.A. van der, Elders, P.J.Mm Heine, R.J., Dekker, J.M., Nijpels, G., Hugtenburg, J.G. Effectiveness of insulin therapy in people with Type 2 diabetes in the Hoorn Diabetes Care System. Diabetic Medicine: 2016, 33(6), 794= 7 802

\begin{tabular}{|l|l|}
\hline $\begin{array}{l}\text { Postprint } \\
\text { Version }\end{array}$ & 1.0 \\
\hline Journal website & http://onlinelibrary.wiley.com/doi/10.1111/dme.13110/abstrac t \\
\hline Pubmed link & $\underline{\text { http://www.ncbi.nlm.nih.gov/pubmed/?term=26946450 }}$ \\
\hline DOI & $10.1111 /$ dme.13110 \\
\hline
\end{tabular}

This is a NIVEL certified Post Print, more info at http://www.nivel.eu

\title{
Effectiveness of insulin therapy in people with Type 2 diabetes in the Hoorn Diabetes Care System
}

\author{
M. R. MAST ${ }^{1,2}$, I. WALRAVEN ${ }^{1,4,5}$, T. HOEKSTRA ${ }^{1,4,6}$, A. P. D. JANSEN ${ }^{1,3}$, A. A. W. A. VAN DER \\ HEIJDEN $^{1,3}$, P. J. M. ELDERS ${ }^{1,3}$, R. J. HEINE ${ }^{7}$, J. M. DEKKER ${ }^{1,4}$, G. NIJPELS ${ }^{1,3}$ AND J. G. \\ HUGTENBURG $^{1,2}$ \\ ${ }^{1}$ EMGO Institute for Health and Care Research, \\ 2Department of Clinical Pharmacology and Pharmacy, \\ ${ }^{3}$ Department of General Practice and Elderly Care Medicine, \\ ${ }^{4}$ Department of Epidemiology and Biostatistics, \\ ${ }^{5}$ Department of Ophthalmology, VU University Medical Centre, \\ ${ }^{6}$ Department of Health Sciences, Faculty of Earth and Life Sciences, VU University, \\ Amsterdam, The Netherlands and \\ ${ }^{7}$ Eli Lilly and Company, Indianapolis, IN, USA
}

\begin{abstract}
Aims

To identify HbAlc trajectories after the start of insulin treatment and to identify clinically applicable predictors of the response to insulin therapy.

Methods

The study population comprised 1203 people with Type 2 diabetes included in the Hoorn Diabetes Care System $(n=9849)$. Inclusion criteria were: age $\geq 40$ years; initiation of insulin during follow-up after failure to reach $\mathrm{HbA} 1 \mathrm{c}$ levels $\leq$ $53 \mathrm{mmol} / \mathrm{mol}(7 \%)$ with oral glucose-lowering agents; and a follow up $\geq 2$ years after initiating insulin. Latent class growth modelling was used to identify trajectories of $\mathrm{HbA1c}$. Subjects considered to be 'off target' had HbA1clevels $\geq$ $53 \mathrm{mmol} / \mathrm{mol}(7.0 \%)$ during one-third or more of the follow-up time, and those considered to be 'on target' had HbAlc levels $\geq 53 \mathrm{mmol} / \mathrm{mol}(7.0 \%)$ during less than one-third of the follow-up time.

Results

Four HbA1c trajectories were identified. Most people (88.7\%) were classified as having a stable $\mathrm{HbAlc}$ trajectory of $\sim 57 \mathrm{mmol} / \mathrm{mol}$ (7.4\%). Only $24.4 \%$ of the people were on target in response to insulin; this was associated with lower $\mathrm{HbAlc}$ levels and a higher age at the start of insulin treatment.

Conclusions
\end{abstract}


Mast, M.R., Walraven, L., Hoekstra, T., Jansen, A.P.D., Heijden, A.A.W.A. van der, Elders, P.J.Mm Heine, R.J., Dekker, J.M., Nijpels, G., Hugtenburg, J.G. Effectiveness of insulin therapy in people with Type 2 diabetes in the Hoorn Diabetes Care System. Diabetic Medicine: 2016, 33(6), 794= 7 802

Using latent class growth modelling, four HbA1c trajectories were identified. A quarter of the people starting insulin were on target. Low HbAlc levels and advanced age at the start of insulin therapy were associated with better response to insulin therapy. Initiating insulin earlier improves the likelihood of achieving and sustaining glycaemic control.

\section{WHAT'S NEW?}

We showed the difficulties in reaching and sustaining a target HbAlc of $\leq 53$ $\mathrm{mmol} / \mathrm{mol}(7.0 \%)$ in the majority of people with Type 2 diabetes, even in a centrally organized managed diabetes care system.

Of the 1203 people initiating insulin therapy, 294 people $(24.4 \%)$ were 'on target', whereas 909 people (75.6\%) were 'off target' with an equal follow-up of 5.5 years. This study suggests that initiating insulin earlier increases the likelihood of achieving and sustaining glycaemic control.

\section{INTRODUCTION}

The guidelines of the American Diabetes Association and the European Association for the Study of Diabetes for the management of Type 2 diabetes recommend target $\mathrm{HbAlc}$ levels of $\leq 53 \mathrm{mmol} / \mathrm{mol}(7.0 \%)$ in the majority of people with Type 2 diabetes $[1,2]$. Most people with Type 2 diabetes require insulin treatment in the course of the disease to achieve these HbAlc targets $[3,4]$. Because of the progressive nature of Type 2 diabetes, many people show a pattern of 'serial failure' as a result of sequential addition of glucose-lowering drugs, including insulin as the final step, and only a minority of these people are able to achieve HbA1c levels $\leq 53$ $\mathrm{mmol} / \mathrm{mol}(7.0 \%)[5,6]$. A recent 24-month retrospective database analysis showed that most of the improvement in glycaemic control was achieved in the first 6 months after insulin initiation, with little further improvement thereafter, despite changes in insulin dose [7].

One study showed that lower initial HbAlc levels at the time of insulin initiation predict a favourable response $[\mathrm{HbA} 1 \mathrm{c}<53 \mathrm{mmol} / \mathrm{mol}(7.0 \%)]$ to insulin therapy within 6 months [8]. Another study defined the response to insulin as achieving an $\mathrm{HbAlc}$ level $<58 \mathrm{mmol} / \mathrm{mol}(7.5 \%)$ or lowering HbAlc level by $>1 \%$. Responders to insulin were older, had a lower BMI, and higher initial HbAlclevels [9]. The latter finding may be attributable to the applied definition of responder, which also included the magnitude of $\mathrm{HbA} 1 \mathrm{c}$ response. Moreover, these studies were retrospective and had short follow-ups, the longest being 2 years $[8,9]$. In clinical practice it is important to understand the factors predicting long-term effectiveness of insulin therapy. Randomized controlled trials have their limitations as they are often conducted in relatively healthy people with Type 2 diabetes under strictly controlled circumstances with a short follow-up. Prospective observational population-based studies are needed to better understand the factors that may affect glycaemic control in people with Type 2 diabetes treated with insulin. In the present study we aimed to analyse the long-term glycaemic control of people with Type 2 diabetes treated with insulin by analysing trajectories of HbAlc levels after the start of insulin therapy and by analysing the sustainability of HbAlc levels over time. An additional objective was to identify clinically applicable predictors of the response to insulin initiation. 
Mast, M.R., Walraven, L., Hoekstra, T., Jansen, A.P.D., Heijden, A.A.W.A. van der, Elders, P.J.Mm Heine, R.J., Dekker, J.M., Nijpels, G., Hugtenburg, J.G. Effectiveness of insulin therapy in people) with Type 2 diabetes in the Hoorn Diabetes Care System. Diabetic Medicine: 2016, 33(6), 794= 7 802

\section{RESEARCH DESIGN AND METHODS}

\section{Study population}

An observational population-based cohort study was performed with data from the West-Friesland Diabetes Care System, described in detail elsewhere [10]. Briefly, the Diabetes Care System organizes the diabetes care in the region of West-Friesland in the Netherlands, a region with 200000 inhabitants and representative of a WesternEuropean population [11]. Of all people with Type 2 diabetes in this region, $96 \%$ participated in the Diabetes Care System.

The services provided by the Diabetes Care System encompass direction to the patient's primary care physician in accordance with the Dutch guidelines for Type 2 diabetes, an annual assessment at the Diabetes Care System, including $\mathrm{HbA1c}$ monitoring, and patient education by nurses and dieticians [12]. People entered the Diabetes Care System in different years and with different diabetes durations. The year of initiating insulin was considered the year of entry in this study (T0).

All the people included in the study were informed and agreed to the use of these records for research purposes. All human studies were approved by the appropriate ethics committee and were performed in accordance with the ethical standards laid down in the declaration of Helsinki.

\section{Study participants}

In the period between 1998 and 2012, 9849 people with Type 2 diabetes entered the Diabetes Care System. For the present study, 1203 people with Type 2 diabetes, who initiated insulin during follow-up were selected from the Diabetes Care System. These people were aged $\geq 40$ years and had a follow-up of at least 2 years after initiation of insulin.

\section{Confirmation of diabetes and diabetes duration}

The date of diabetes diagnosis was self-reported and confirmed in the records of the primary care physician if at least one of the following was reported: (1) one or more classic symptoms plus one fasting plasma glucose value $\geq 7.0 \mathrm{mmol} / \mathrm{l}$ ) or a random plasma glucose value $11.1 \mathrm{mmol} / \mathrm{l}$ and (2) at least two elevated plasma glucose concentrations on different occasions (fasting glucose $\geq 7.0 \mathrm{mmol} / 1$ or random plasma glucose $\geq 11.1 \mathrm{mmol} / \mathrm{l}$ ) in the absence of symptoms. Diabetes duration was calculated from the date of diabetes diagnosis until the date of insulin initiation.

\section{Measurements}

HbA1c levels were assessed with a Diabetes Control and Complications Trialstandardized reversed-phase cation exchange chromatography HA 8160 Analyzer (Menarini, Florence, Italy). The HbAlc level was detected by a dual-wavelength colorimetric (415-500) assay. The intra-assay coefficient of variation was $0.6 \%$ at a mean level of $4.9 \%$ and the interassay coefficient of variation was $0.8 \%$ at a mean level of $5.5 \%$.

Weight and height were measured annually (while people were barefoot and wearing light clothes). BMI was calculated by dividing weight $(\mathrm{kg})$ by the square of height (m). Difference in weight was calculated by subtracting the weight at end of followup from the weight at the start of insulin.

Blood pressure was measured annually. Systolic blood pressure was measured three times on the right arm after $5 \mathrm{~min}$ rest in a seated position using a random-zero sphygmanometer with different oscillometric devices over time. 
Mast, M.R., Walraven, L., Hoekstra, T., Jansen, A.P.D., Heijden, A.A.W.A. van der, Elders, P.J.Mm Heine, R.J., Dekker, J.M., Nijpels, G., Hugtenburg, J.G. Effectiveness of insulin therapy in people with Type 2 diabetes in the Hoorn Diabetes Care System. Diabetic Medicine: 2016, 33(6), $794=7$ 802

Fasting glucose levels were assessed in venous plasma using the glucose-oxidase method (Glucoquant/hexokinase/G6P-DH; Boehringer-Mannheim, Mannheim, Germany).

Triglycerides, total and HDL cholesterol were determined from fasting blood samples by enzymatic techniques (Boehringer-Mannheim, Mannheim, Germany). All measurements were performed at the clinical chemistry laboratory of the Westfries Gasthuis.

Microalbuminuria was considered present if the urine albumin/creatinine ratio was $>$ $2.0 \mathrm{mg} / \mathrm{mmol}$. Retinopathy (fundus photography of both eyes was performed yearly) was measured from 1998 until 2012, with various fundus cameras (e.g. the Kowa Pro Fundus camera, non-mydriatic Canon CR5 camera, nonmydriatic Topcon TRC NW 100 camera), using 45-degree fundus photographs after mydriasis with $0.5 \%$ tropicamide and $2.5 \%$ phenylephrine eye drops. All photographs were graded by an experienced ophthalmologist according to the EURODIAB classification score [13]. Retinopathy at the end of follow-up was calculated for each person at the end of her/his follow-up period.

\section{Primary care physician organizations}

Diabetes management differs across primary care physicians practices; therefore, primary care physicians organizations were categorized into three types: involvement of a nurse practitioner in diabetes management who initiates insulin; involvement of a nurse practitioner and insulin initiation transferred to Diabetes Care System; and no nurse practitioner and insulin initiation transferred to Diabetes Care System. Information on medication use was registered yearly at the annual visit by checking the dispensing labels of the medication brought in by people with Type 2 diabetes.

\section{Statistical analysis}

Latent class growth modelling (LCGM) is a type of cluster analysis used to group patients into an optimum number of groups, each with an unique trajectory of HbA1c over time, by modelling heterogeneity in the time course [14, 15]. Each class has its own growth measures (i.e. intercept, slope). To determine the optimum number of classes, a stepwise forward approach was taken, starting with a model with one developmental pattern. Subsequently, one class at a time was added. The optimum model is a model where individuals within a class are most similar to each other and most different from individuals in other classes. The model fit was assessed by the Bayesian information criterion (where a lower Bayesian information criterion indicates a better fit) and with posterior probabilities (where probabilities $>$ 0.8 are recommended and a probability closer to 1 indicates a better classification) [14]. Also, the usefulness and clinical interpretation of each new derived class was assessed. Usefulness was assessed by considering the number of people in each class (hereby rejecting small classes consisting of $<1 \%$ of the total study population). The final number of classes was based on a low Bayesian information criterion score, good probabilities $(>0.8)$, and clinically relevant differences between classes. The number of missing values were small in this study and at random. Missing data at random do not affect model estimates in LCGM.

Demographic characteristics including HbAlc, BMI, systolic blood pressure, fasting glucose, cholesterol, triglycerides, retinopathy, microalbuminuria and diabetes duration at baseline were assessed. The mean difference in weight gain for participants in each class was calculated, as well as the percentage of people treated 
Mast, M.R., Walraven, L., Hoekstra, T., Jansen, A.P.D., Heijden, A.A.W.A. van der, Elders, P.J.Mm Heine, R.J., Dekker, J.M., Nijpels, G., Hugtenburg, J.G. Effectiveness of insulin therapy in people ) with Type 2 diabetes in the Hoorn Diabetes Care System. Diabetic Medicine: 2016, 33(6), 794= 7 802

with oral glucose-lowering agents in addition to insulin, in each class. Finally, the percentage of prevalent retinopathy at the end of follow-up for each person in each class was assessed.

Differences in the above variables between the trajectories were tested with oneway anova and post hoc Bonferroni tests for mean levels, with chi-squared tests for proportions and a Kruskal-Wallis test for median levels in the study population. Subsequently, multivariate logistic backward regression analyses were used to assess which characteristics (e.g. sex, age, HbA1c, BMI, systolic blood pressure, diabetes duration, triglycerides and cholesterol) at the initiation of insulin were associated with membership of the groups. Group 1 was regarded as the reference group. To analyse the sustainability of the HbA1c levels over time, the proportion of people with Type 2 diabetes who were 'off target' and 'on target' was calculated. People were considered to be off target when HbA1c levels were $>53 \mathrm{mmol} / \mathrm{mol}(7.0 \%)$ during one-third or more of the follow-up time, and to be on target when $\mathrm{HbA} 1 \mathrm{c}$ levels were $>53 \mathrm{mmol} / \mathrm{mol}(7.0 \%)$ during less than one-third of the followup time.

Differences in the demographic characteristics, HbA1c, BMI, systolic blood pressure, fasting glucose, cholesterol, triglycerides, retinopathy, microalbuminuria, metformin use only, sulphonylurea use only, metformin and sulphonylurea combination use, other combination use at baseline, and diabetes duration at baseline between the off-target group and on-target group were tested with onewayanova and post hoc Bonferroni tests for mean levels, with chi-squared tests for proportions and a Kruskal-Wallis test for median levels in the study population. Subsequently, multivariate logistic backward regression analysis was used to assess which person characteristics (e.g. BMI) and disease determinants (e.g. diabetes duration and $\mathrm{HbAlc}$ ) before the initiation of insulin were associated with membership of the on-target group. The off-target group was regarded as reference class. All analyses were adjusted for age and sex, in other words sex and age were forced in the multivariable model. All determinants were entered simultaneously using the backward elimination method, leading to a model including only significant $(\mathrm{P}<0.05)$ determinants.

The proportional hazards assumption, i.e. the constant hazard ratio over time, was evaluated by comparing estimated log-log survival curves for all covariates. All assessed log-log survival plots graphically showed two parallel lines, indicating no violation of the assumption. All continuous variables were divided into quartiles to check whether these variables met the proportional hazard assumption. Data are presented as odds ratios (ORs) with $95 \%$ CIs. P values $<0.05$ were taken to indicate statistical significance.

The LCGM analyses were conducted with Mplus 7.11. Other statistical analyses were performed with spss for Windows (version 20.0, SPSS Inc., Chicago, IL, USA).

\section{RESULTS}

Figure 1 shows the disposition of the 1203 people with Type 2 diabetes participating in the present study, with a mean (range) follow-up of 5.6 (2-10) years. 
Mast, M.R., Walraven, L., Hoekstra, T., Jansen, A.P.D., Heijden, A.A.W.A. van der, Elders, P.J.Mm Heine, R.J., Dekker, J.M., Nijpels, G., Hugtenburg, J.G. Effectiveness of insulin therapy in people with Type 2 diabetes in the Hoorn Diabetes Care System. Diabetic Medicine: 2016, 33(6), 794= 7 802

\section{[FIGURE 1]}

\section{HbA1c trajectories}

Using LCGM, we identified four groups of distinct HbA1c trajectories.

Figure 2 shows the trajectories of HbAlc over 10 years for the four identified groups after the initiation of insulin. HbA1c levels 2 years before the initiation of insulin were shown as well. By far the largest group (group 1, $\mathrm{n}=1067,88.7 \%$ ) consisted of people who had stable HbA1c levels during follow-up of $\sim 57 \mathrm{mmol} / \mathrm{mol}(7.4 \%)$. Group $2(\mathrm{n}=47,3.9 \%)$ comprised people who had very high HbA1c levels of 95 $\mathrm{mmol} / \mathrm{mol}(10.8 \%)$ at initiation of insulin, which thereafter gradually decreased to 73 $\mathrm{mmol} / \mathrm{mol}(8.8 \%)$ over a 10 -year period. Group $3(\mathrm{n}=36,3.0 \%)$ had a steadily increasing $\mathrm{HbA} 1 \mathrm{c}$ level after the initiation of insulin therapy, from a baseline level of $65 \mathrm{mmol} / \mathrm{mol}(8.1 \%)$ to $92 \mathrm{mmol} / \mathrm{mol}(10.6 \%)$ at 3 years. Group $4(\mathrm{n}=53,4.4 \%)$ comprised people who had high HbAlc levels starting at $85 \mathrm{mmol} / \mathrm{mol}(9.9 \%)$ that decreased over the years to around target levels of $51 \mathrm{mmol} / \mathrm{mol}(6.8 \%)$.

\section{[FIGURE 2]}

Table 1 shows the characteristics of the four groups determined by LCGM analysis. Table 2 shows the results of the multinomial logistic regression analysis. People in groups 2, 3 and 4 had significantly higher baseline levels compared with those in group 1. People in group 3 were younger compared with those in group 1. People in group 4 were using significantly more sulphonylurea only compared with the other groups (20.8 vs 15.1, 2.1 and 5.6\%). The total mortality in group 4 was significantly higher compared with the other groups $(30.2$ vs $13.9,14.9$ and $2.8 \% ; \mathrm{P}=0.002)$.

\section{[TABLE 1][TABLE 2]}

Of the 1203 people initiating insulin therapy, 294 people (24.4\%) were on target, whereas 909 people $(75.6 \%)$ were off target, with an equal follow-up of 5.5 years. People in the off-target group were significantly younger, and had higher HbAlc and glucose levels at the initiation of insulin. More people in the off-target group were using a combination of metformin and sulphonylureas (Table 4). There was no difference in total mortality between the off-target and the on-target groups (14.0 vs $16.0 \%)$.

Table 3 shows which characteristics were associated with the membership of the ontarget group compared with the off-target group. People within the on-target group had statistically significantly lower HbAlc levels before the initiation of insulin (OR $0.69,95 \%$ CI 0.62 to 0.78$)$.

\section{[TABLE 3][TABLE 4][FIGURE 3]}

\section{DISCUSSION}

Four distinct trajectories of HbA1c were identified with LCGM in people with Type 2 diabetes initiating insulin. Only $24.4 \%$ of the people showed a 'good response' to insulin during follow-up. These were the older people with a lower HbA1c level at the start of insulin treatment.

A previous study, consistent with the present findings, showed that a lower HbA1c level at the start of insulin treatment was associated with a higher likelihood of reaching the on-target group [8, 16-19]; however, the previous studies were 
Mast, M.R., Walraven, L., Hoekstra, T., Jansen, A.P.D., Heijden, A.A.W.A. van der, Elders, P.J.Mm Heine, R.J., Dekker, J.M., Nijpels, G., Hugtenburg, J.G. Effectiveness of insulin therapy in people with Type 2 diabetes in the Hoorn Diabetes Care System. Diabetic Medicine: 2016, 33(6), $794=7$ 802

shorter (up to 1 year), and the defined target did not include sustained glycaemic control. In the UK Prospective Diabetes Study (UKPDS), patients in the intensive treatment group (treated with insulin) reached a median HbAlc level of 53 $\mathrm{mmol} / \mathrm{mol}(7.0 \%)$ over 10 years [20], but the baseline HbA1c values of the 911 patients initiating insulin in the UKPDS were much lower than those of the patients in the present study [43 $\mathrm{mmol} / \mathrm{mol}(6.0 \%)$ vs $63 \mathrm{mmol} / \mathrm{mol}(8.0 \%)]$ and, in contrast to the present study, the UKPDS included newly diagnosed people with Type 2 diabetes [20].

A considerable number of people $(n=294)$ with Type 2 diabetes had good glycaemic control in the year before initiation of insulin therapy. The reason for initiation of insulin in these people is not clear. Primary care physicians may have based their decision to initiate insulin on further $\mathrm{HbAl}$ cmeasurements and on other undefined reasons. It is also possible that the people with Type 2 diabetes were experiencing side effects of oral glucose-lowering agents, and were prepared and mentally ready to start insulin therapy.

Taken together, these data strongly suggest that initiating insulin earlier increases the likelihood of achieving and sustaining glycaemic control [21-23]. Early intensive insulin therapy has been shown to improve $\beta$-cell function with a long-lasting beneficial effect on glycaemic control $[23,24]$. The obvious risk of the availability of multiple oral agents is that insulin therapy will be unduly delayed in people with poor glycaemic control $[25,26]$.

The mortality rate in group 4 was higher compared with the other groups, despite similar baseline values. The higher mortality rate could be explained by the higher rate of glucose-lowering in this group and subsequently the risk of hypoglycaemia. This is consistent with the results from the ACCORD study, the Veterans Affairs Trial as well as the General Practice Research Database [27-29]. It is interesting to note that people in class 2 also had poor $\mathrm{HbAlc}$ levels at baseline, but the reduction in HbA1c during follow-up was less rapid and not associated with excess mortality. There are some limitations to consider. This study was performed in a centrally organized managed diabetes care system, in which a strict treatment algorithm [30] was applied by all caregivers in this region, therefore, this cohort is by no means representative of diabetes care in other regions; however, this cohort provided the optimum circumstances to address the current study question. It will be of great interest to perform a similar analysis in a different treatment setting. The identified determinants of successfully achieving glycaemic control corroborate earlier findings and were probably not affected by this study cohort $[17,18]$. Other limitations were that insulin doses and adherence to the insulin titration algorithm were not collected. Finally, we don't have information on comorbidities.

The use of LCGM as a method to define groups with distinct trajectories has some limitations. The first limitation concerns the complexity and flexibility of the model, and each decision could influence the final number of classes. Furthermore, LCGM can lead to an imbalance in the number of subjects in each trajectory. As a result of this, extraction of the classes is a simplification of the reality and does not necessarily reflect the true existence of multiple subgroups [14]. The strength of LCGM, however, is that categorization is not based on subgroups determined a priori, but is based on trajectory characteristics of HbAlc within the data. Further, LCGM is focused on relationships among individuals, and creates the condition required to categorize them in homogenous subgroups. To our knowledge, this is the 
Mast, M.R., Walraven, L., Hoekstra, T., Jansen, A.P.D., Heijden, A.A.W.A. van der, Elders, P.J.Mm Heine, R.J., Dekker, J.M., Nijpels, G., Hugtenburg, J.G. Effectiveness of insulin therapy in people with Type 2 diabetes in the Hoorn Diabetes Care System. Diabetic Medicine: 2016, 33(6), Z94= 7 802

first population-based observational Type 2 diabetes cohort study using LCGM to define trajectories of $\mathrm{HbAlc}$ in patients initiating insulin. Other strengths of the present study are the completeness of the measurements, the long follow-up after the initiation of insulin, information on $\mathrm{HbAlc}$ levels before the initiation of insulin, the standardized yearly measurements, our definitions of on target and off target, which were simple and are easy to replicate in other Type 2 diabetes populations but have not been described before.

In summary, the present study showed four distinct groups of HbAlc trajectories in people with Type 2 diabetes initiating insulin therapy. A lower HbA1c level at baseline was associated with better glycaemic response to insulin. Initiating insulin earlier in the course of Type 2 diabetes, when HbAlclevels are only modestly elevated, increases the probability of achieving and sustaining target glycaemic values.

The on-target group may represent a subgroup with a less progressive disease; however, the group with a rapidly lowering HbAlc after insulin initiation had a higher mortality. This might imply that less strict glucose-lowering is desirable in some categories of people with Type 2 diabetes and that 'personalized care' is necessary.

\section{FUNDING SOURCES}

This project was supported by a BRIDGES grant from the International Diabetes Federation. BRIDGES, an International Diabetes Federation project, is supported by an unrestricted educational grant from Lilly Diabetes and supported by the Diabetes Care System.

\section{COMPETING INTERESTS}

R.J.H. is an employee and stock holder at Eli Lilly \& Company, Indianapolis IN, USA. The remaining authors have no competing interests to declare.

\section{ACKNOWLEDGEMENTS}

We thank all general practitioners in the West-Friesland region for their contributions to the study. We also thank the research assistants and staff of the Hoorn Diabetes Care System, the Netherlands for the enormous amount of work they did in collecting all of the data.

\section{REFERENCES}

1 American Diabetes Association. Standards of Medical Care in Diabetes 2012. Diabetes Care 2012; 35 (Suppl. 1): S11-S63.

2 Raz I, Riddle MC, Rosenstock J, Buse JB, Inzucchi SE, Home PD et al. Personalized management of hyperglycemia in type 2 diabetes: reflections from a diabetes care editors expert forum. Diabetes Care 2013; 36: 1779-1788.

3 Khunti K, Wolden ML, Thorsted BL, Andersen M, Davies MJ.

Clinical Inertia in People With Type 2 Diabetes: A retrospective cohort study of more than 80,000 people. Diabetes Care 2013; 36: 3411-3417.

4 Del Prato S, Penno G, Miccoli R. Changing the treatment paradigm for type 2 diabetes. Diabetes Care 2009; 32(Suppl. 2): S217-S222.

5 Turner RC, Cull CA, Frighi V, Holman RR, for the UK Prospective Diabetes Study (UKPDS) Group. Glycemic control with diet, sulfonylurea, metformin, or insulin in patients with type 2 diabetes mellitus: Progressive requirement for multiple therapies (ukpds 49). JAMA 1999; 281: 2005-2012. 
Mast, M.R., Walraven, L., Hoekstra, T., Jansen, A.P.D., Heijden, A.A.W.A. van der, Elders, P.J.Mm Heine, R.J., Dekker, J.M., Nijpels, G., Hugtenburg, J.G. Effectiveness of insulin therapy in people with Type 2 diabetes in the Hoorn Diabetes Care System. Diabetic Medicine: 2016, 33(6), 794 802

6 Holman RR, Thorne KI, Farmer AJ, Davies MJ, Keenan JF, Paul S et al. Addition of Biphasic, Prandial, or Basal Insulin to Oral Therapy in Type 2 Diabetes. N Engl J Med 2007; 357: 1716- 1730 .

7 Watson L, Wilson BP, Alsop J, Kumar S. Weight and glycaemic control in type 2 diabetes: what is the outcome of insulin initiation? Diabetes Obes Metab 2011; 13: 823-831.

8 Hanefeld M, Fleischmann H, Schiffhorst G, Bramlage P. Predictors of response to early basal insulin treatment in patients with type 2 diabetes-the EARLY experience. Diabetes Technol Ther 2014; 16: 241-246.

9 Owen V, Seetho I, Idris I. Predictors of responders to insulin therapy at 1 year among adults with type 2 diabetes. Diabetes Obes Metab 2010; 12: 865-870.

10 Zavrelova H, Hoekstra T, Alssema M, Welschen LMC, Nijpels G, Moll AC et al. Progression and regression: distinct developmental patterns of diabetic retinopathy in patients with type 2 diabetes treated in the diabetes care system West-Friesland, the Netherlands.

Diabetes Care 2011; 34: 867-872.

11 CBS Statistics Netherlands. Inhabitants West-Friesland, The Netherlands. 2011 Available at http://www.cbs.nl/NR/rdonlyres/ 91AF11E5-E30A-4C15-BD05ODD67599E245/0/2012a3pub.pdf.

Last accessed 30 November 2015.

12 Welschen L, van Oppen P, Bot S, Kostense P, Dekker J, Nijpels G.

Effects of a cognitive behavioural treatment in patients with type 2 diabetes when added to managed care; a randomised controlled trial. J Behav Med 2013; 36: 556-566.

13 Aldington SJ, Kohner EM, Meuer S, Klein R, Sjolie AK. Methodology for retinal photography and assessment of diabetic retinopathy: the EURODIAB IDDM complications study. Diabetologia 1995; 38: 437-444.

14 Twisk J, Hoekstra T. Classifying developmental trajectories over time should be done with great caution: a comparison between methods. J Clin Epidemiol 2012; 65: 1078-1087.

15 Jung T, Wickrama KAS. An introduction to latent class growth analysis and growth mixture modeling. Soc Pers Psychol Compass 2007; 2: 302-317.

16 Nichols GA. Understanding Clinical Inertia: Are Patient or Provider Characteristics Predictive of Glycemic Control. Poster presentation at the 73rd Scientific Sessions of the American Diabetes Association, Chicago, 2013. Available at http://www.ajmc.com/journals/ issue/2015/2015-vol21-n9/do-patient-or-provider-characteristicsimpact- management-ofdiabetes/p-3\#sthash.LWDnQaEl.dpuf Last accessed 23 December 2015.

17 Dale J, Martin S, Gadsby R. Insulin initiation in primary care for patients with type 2 diabetes: 3-year follow-up study. Prim Care Diabetes 2010; 4: 85-89.

18 Nichols GA, Kimes TM, Harp JB, Kou TD, Brodovicz KG.

Glycemic Response and Attainment of A1C Goals Following Newly Initiated Insulin Therapy for Type 2 Diabetes. Diabetes Care 2012; 35: 495-497.

19 Kawamori R, Node K, Hanafusa T, Atsumi Y, Naito Y, Oka Y.

Baseline and 1-year interim follow-up assessment of Japanese patients initiating insulin therapy who were enrolled in the cardiovascular risk evaluation in people with type 2 diabetes on insulin therapy study: an international, multicenter, observational study. Cardiovasc Diabetol 2013; 12: 131.

20 Intensive blood-glucose control with sulphonylureas or insulin compared with conventional treatment and risk of complications in patients with type 2 diabetes (UKPDS 33) The Lancet 1998; 352: 837-853.

21 Kumar S. Second line therapy: type 2 diabetic subjects failing on metforminGLP-1.DPPIVinhibitors versus sulphonylurea.insulin: For GLP-1.DPP-IV inhibitors. Diabetes Metab Res Rev 2012; 28: 21-25.

22 Holman RR, Paul SK, Bethel MA, Matthews DR, Neil HA. 10- Year Follow-up of Intensive Glucose Control in Type 2 Diabetes. N Engl J Med 2008; 359: 1577-1589.

23 Ertek S, Cetinkalp S. Is there U-turn from insulin back to pills in diabetes. Curr Vasc Pharmacol 2014; 12: 617-626.

24 Yki-J€arvinen H. Glucose toxicity. Endocr Rev 1992; 13: 415-431.

25 Cefalu WT, Riddle MC. SGLT2 inhibitors: the latest "new kids on the block"!. Diabetes Care 2015; 38: 352-354. 
Mast, M.R., Walraven, L., Hoekstra, T., Jansen, A.P.D., Heijden, A.A.W.A. van der, Elders, P.J.Mm Heine, R.J., Dekker, J.M., Nijpels, G., Hugtenburg, J.G. Effectiveness of insulin therapy in people with Type 2 diabetes in the Hoorn Diabetes Care System. Diabetic Medicine: 2016, 33(6), $794=7$ 802

26 Inzucchi SE, Bergenstal RM, Buse JB. Management of hyperglycemia in type 2 diabetes 2015: a patient-centered approach: update to a position statement of the American Diabetes Association and the European Association for the Study of Diabetes.

Diabetes Care 2015; 38: 140-149.

27 Currie CJ, Poole CD, Evans M, Peters JR, Morgan CL. Mortality and Other Important Diabetes-Related Outcomes With Insulin vs Other Antihyperglycemic Therapies in Type 2 Diabetes. J Clin Endocrinol Metab 2013; 98: 668-677.

28 Abraira C, Colwell J, Nuttall F, Sawin CT, Henderson W, Comstock JP et al.

Cardiovascular events and correlates in the Veterans Affairs Diabetes Feasibility Trial.

Veterans Affairs Cooperative Study. Arch Intern Med 1997; 157: 188.

29 ACCORD Study Group, Gerstein HC, Miller ME, Byington RP, Goff DC, Bigger JT et al. Effects of intensive glucose lowering in type 2 diabetes. N Engl J Med 2008; 358: 25452559.

30 Behandelprotocol Diabetes Zorg Systeem. Available at http:// www.diabeteszorgsysteem.nl/wp-content/uploads/2014/02/Behandelprotocol- 2014.pdf Last accesed 23 December 2015. 
Mast, M.R., Walraven, L., Hoekstra, T., Jansen, A.P.D., Heijden, A.A.W.A. van der, Elders, P.J.Mm Heine, R.J., Dekker, J.M., Nijpels, G., Hugtenburg, J.G. Effectiveness of insulin therapy in people with Type 2 diabetes in the Hoorn Diabetes Care System. Diabetic Medicine: 2016, 33(6), 794= 7 802

\section{TABLES AND FIGURES}

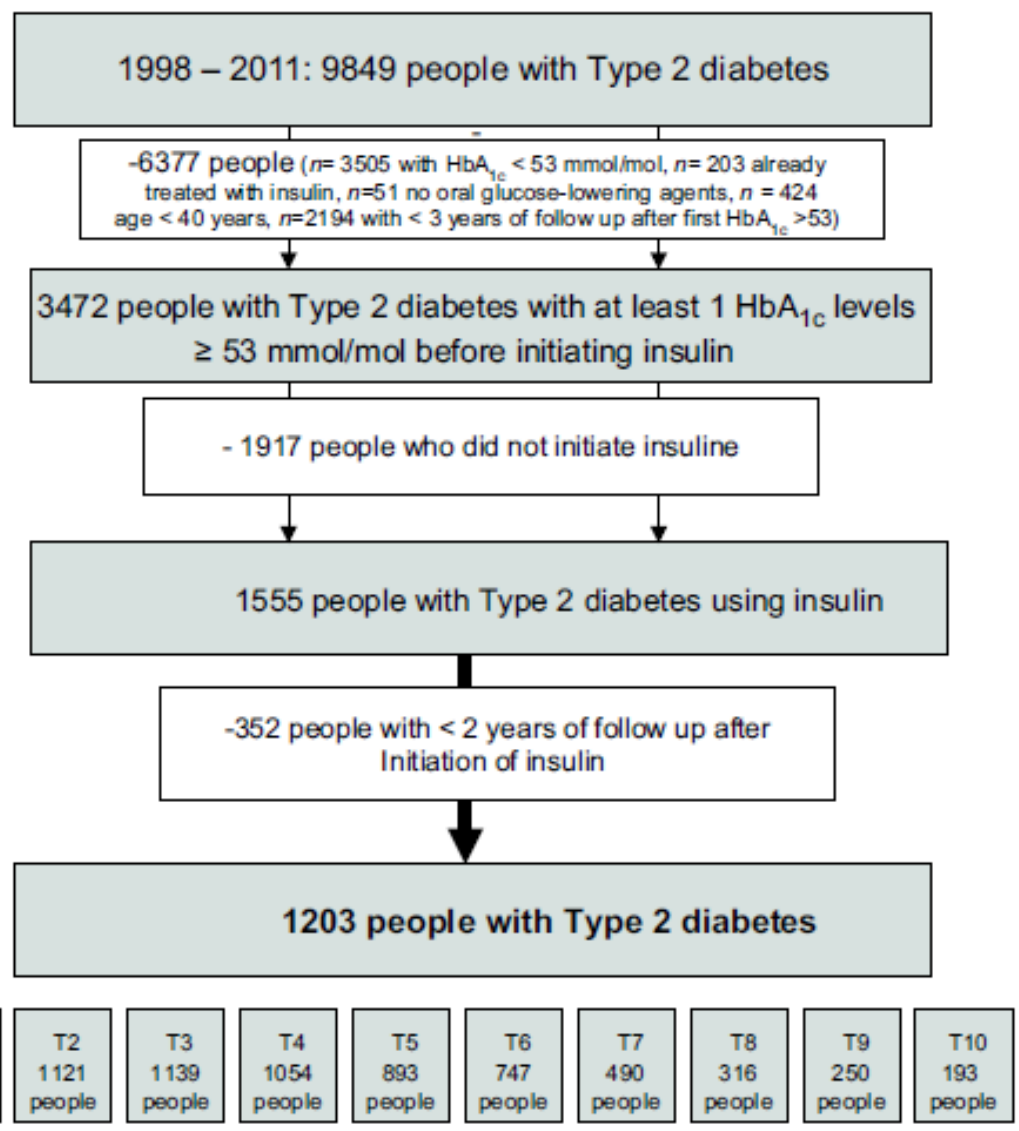

FGURE 1 Flowchart of the included people with Type 2 diabetes.

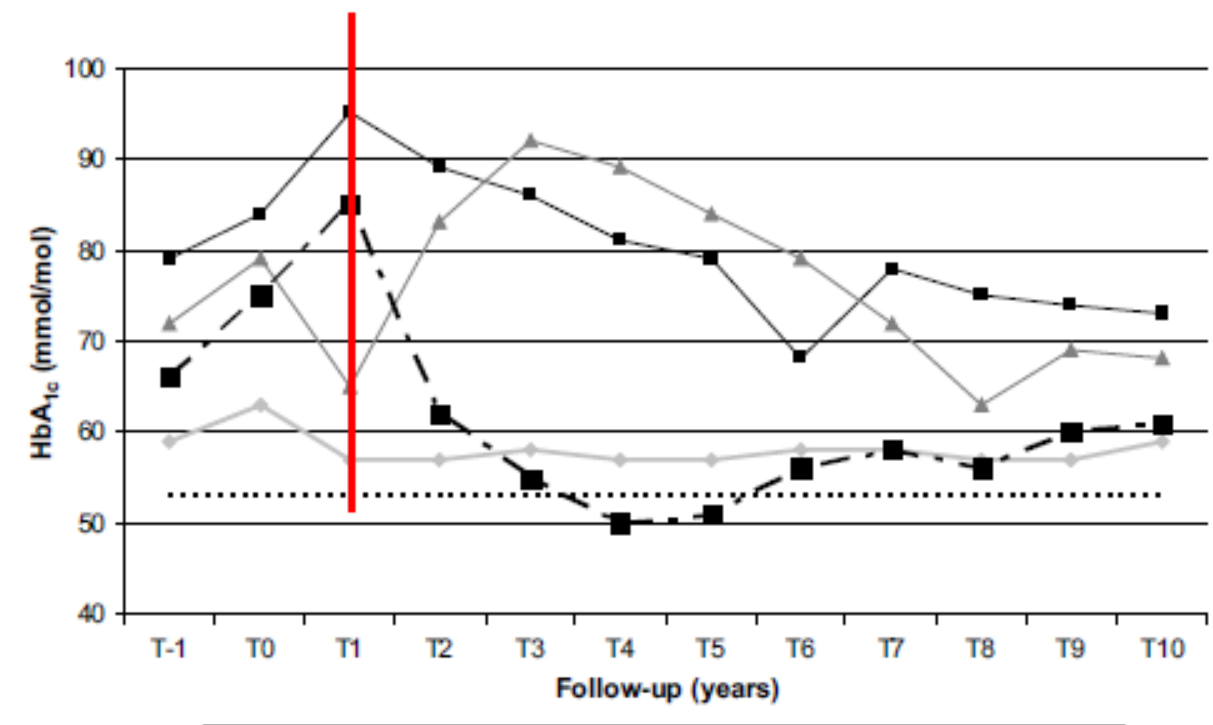

class $1 \longrightarrow$ - class $2 \longrightarrow$ class $3-\mathbf{E}-$ class $4 \cdots \cdots \cdot$ Target

Abbreviation: Red line: initiation of insulin

FGURE 2 Trajectories of $\mathrm{HbA}_{1 \mathrm{c}}$ over 10 years in four groups of people with Type 2 diabetes after initiation of insul in. 
Mast, M.R., Walraven, L., Hoekstra, T., Jansen, A.P.D., Heijden, A.A.W.A. van der, Elders, P.J.Mm Heine, R.J., Dekker, J.M., Nijpels, G., Hugtenburg, J.G. Effectiveness of insulin therapy in people with Type 2 diabetes in the Hoorn Diabetes Care System. Diabetic Medicine: 2016, 33(6), 794 802

nive

Table 1 Baseline characteristics of the people with Type 2 diabetes in the various $\mathrm{HbA}_{1 \mathrm{c}}$ trajectory groups after initiation of insulin therapy

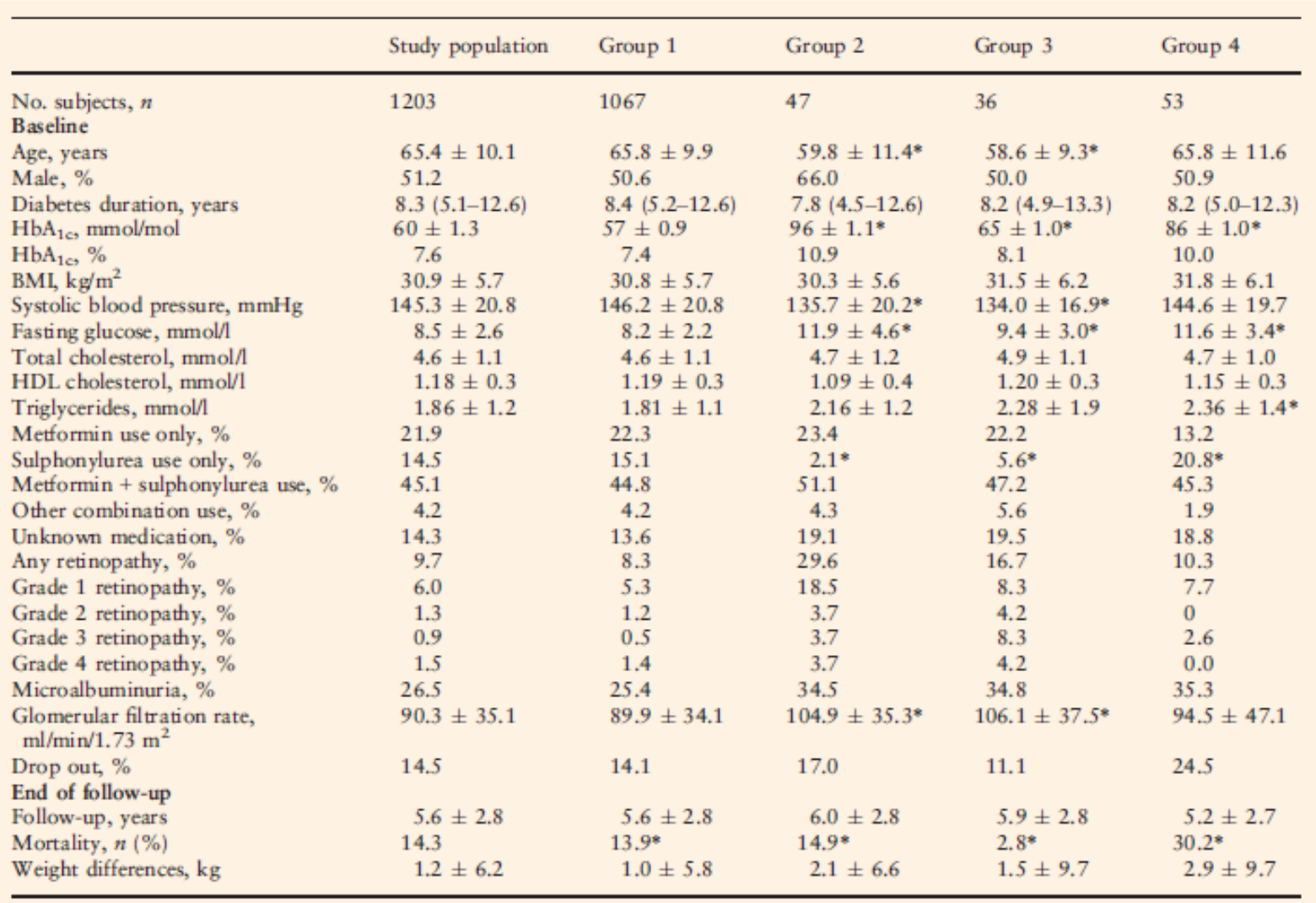

Data represent mean \pm SD, proportions, or median (interquartile range). Between-cluster differences were tested with ANova and post hoc Bonferroni for mean levels, with chi-squared tests for proportions and Kruskal-Wallis test for median levels.

*Statistically significantly $(P<0.05)$ different from class 1 .

Table 2 Multivariate regression analyses determining characteristics of different groups, compared to group 1

\begin{tabular}{|c|c|c|}
\hline & $\begin{array}{l}\text { Model } 1 \\
\text { OR }(95 \% \text { CI) }\end{array}$ & $\begin{array}{l}\text { Model } 2 \\
\text { OR }(95 \% \text { CI) }\end{array}$ \\
\hline \multicolumn{3}{|l|}{ Group 2 vs group 1} \\
\hline Male & $0.81(0.25$ to 2.57$)$ & \\
\hline Age, years & $0.97(0.92$ to 1.03$)$ & $0.96(0.91$ to 1.01$)$ \\
\hline $\mathrm{HbA}_{1 \mathrm{c}}, \mathrm{mmol} / \mathrm{mol}$ & $41.60(17.93 \text { to } 96.70)^{*}$ & $47.56(20.84 \text { to } 108.56)^{*}$ \\
\hline Glucose, $\mathrm{mmol} / \mathrm{l}$ & $1.03(0.87$ to 1.23$)$ & \\
\hline Systolic blood pressure, $\mathrm{mmHg}$ & $0.99(0.96$ to 1.02$)$ & \\
\hline Triglycerides, $\mathrm{mmol} / \mathrm{l}$ & $1.35(0.90$ to 2.05$)$ & \\
\hline \multicolumn{3}{|l|}{ Group 3 vs group 1} \\
\hline Male & $1.11(0.51$ to 2.46$)$ & \\
\hline Age, years & $0.95(0.91 \text { to } 0.99)^{*}$ & $0.93(0.89 \text { to } 0.97)^{*}$ \\
\hline $\mathrm{HbA}_{1 \mathrm{c}}, \mathrm{mmol} / \mathrm{mol}$ & $1.81(1.16 \text { to } 2.84)^{*}$ & $2.08(1.41 \text { to } 3.07)^{*}$ \\
\hline Glucose, $\mathrm{mmol} / \mathrm{l}$ & $1.09(0.93$ to 1.29$)$ & \\
\hline Systolic blood pressure, $\mathrm{mmHg}$ & $0.97(0.95 \text { to } 0.99)^{*}$ & \\
\hline Triglycerides, $\mathrm{mmol} / \mathrm{l}$ & $1.20(0.97$ to 1.49$)$ & \\
\hline \multicolumn{3}{|l|}{ Group 4 vs group 1} \\
\hline Male & $0.78(0.31$ to 1.97$)$ & \\
\hline Age, years & $1.01(0.97$ to 1.06$)$ & $1.01(0.97$ to 1.05$)$ \\
\hline $\mathrm{HbA}_{1 \mathrm{c}}, \mathrm{mmol} / \mathrm{mol}$ & $18.18(9.03 \text { to } 36.59)^{*}$ & $20.86(10.46 \text { to } 41.60)^{*}$ \\
\hline Glucose, $\mathrm{mmol} / 1$ & $1.05(0.90$ to 1.23$)$ & \\
\hline Systolic blood pressure, $\mathrm{mmHg}$ & $1.00(0.98$ to 1.02$)$ & \\
\hline Triglycerides, $\mathrm{mmol} / \mathrm{l}$ & $1.33(0.99$ to 1.78$)$ & \\
\hline
\end{tabular}

OR, odds ratio.

${ }^{*}$ Indicates a significant association $(P<0.05)$. Model 1 shows the multivariate model including determinants with $P$ values $<0.10$. Model 2 shows the final model after backward selection, including variables with $P$ values $<0.05$. Nagelkerke Rsquare is 0.61 . 
Mast, M.R., Walraven, L., Hoekstra, T., Jansen, A.P.D., Heijden, A.A.W.A. van der, Elders, P.J.Mm Heine, R.J., Dekker, J.M., Nijpels, G., Hugtenburg, J.G. Effectiveness of insulin therapy in people with Type 2 diabetes in the Hoorn Diabetes Care System. Diabetic Medicine: 2016, 33(6), $794=$ 802

Table 3 Main identified determinants of on target vs off target response to insulin therapy

\begin{tabular}{lll}
\hline & $\begin{array}{l}\text { Univariate } \\
\text { OR }(95 \% \mathrm{CI})\end{array}$ & $\begin{array}{l}\text { Multivariable } \\
\text { OR }(95 \% \mathrm{CI})\end{array}$ \\
\hline Sex (female) & $0.94(0.72-1.22)$ & $0.85(0.65-1.12)$ \\
$\mathrm{Age}($ years $)$ & $1.03(1.01-1.04)^{*}$ & $0.69(0.62-0.78)^{*}$ \\
$\mathrm{HbA}(\mathrm{mmol} / \mathrm{mol})$ & $0.68(0.61-0.76)^{*}$ & $1.02(1.01-1.04)^{*}$ \\
$\mathrm{BMI}\left(\mathrm{kg} / \mathrm{m}^{2}\right)$ & $1.01(0.99-1.04)$ & \\
Diabetes duration & $1.00(0.98-1.02)$ & \\
\hline
\end{tabular}

OR, odds ratio.

*Indicates a significant association $(P<0.05)$. Model 1 shows univariate associations with class membership. Model 2 shows the final model after backward selection.

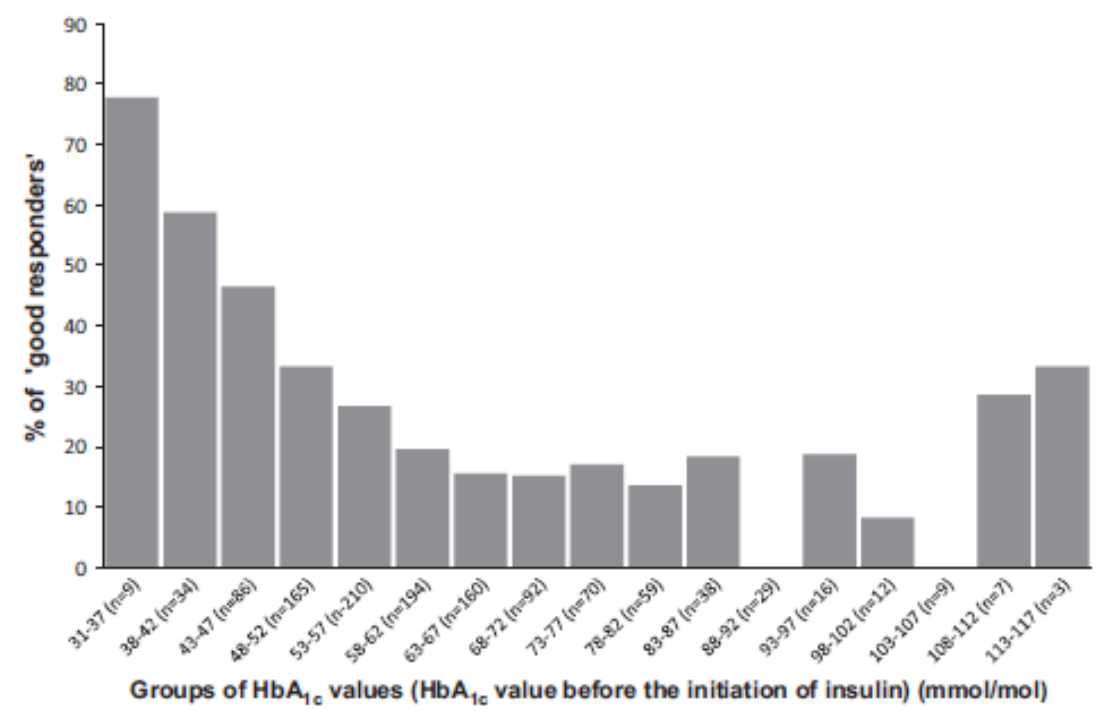

FGURE 3 Percentage of people on target in response to insulin therapy stratified by $\mathrm{HbA}_{1 \mathrm{c}}$ value before initiation of insulin. 
Mast, M.R., Walraven, L., Hoekstra, T., Jansen, A.P.D., Heijden, A.A.W.A. van der, Elders, P.J.Mm Heine, R.J., Dekker, J.M., Nijpels, G., Hugtenburg, J.G. Effectiveness of insulin therapy in people with Type 2 diabetes in the Hoorn Diabetes Care System. Diabetic Medicine: 2016, 33(6), Z94= 7 802

Table 4 Baseline characteristics of the people in the off-target group and on-target groups

\begin{tabular}{|c|c|c|}
\hline & $\begin{array}{l}\text { On-target } \\
\text { group }\end{array}$ & $\begin{array}{l}\text { Off-target } \\
\text { group }\end{array}$ \\
\hline$n(\%)$ & $294(24.4)$ & $909(75.6)$ \\
\hline \multicolumn{3}{|l|}{ Baseline } \\
\hline Age, years & $67.3 \pm 9.9^{*}$ & $64.8 \pm 10.1^{*}$ \\
\hline Male, \% & 52.4 & 50.8 \\
\hline $\begin{array}{l}\text { Diabetes duration, } \\
\text { years }\end{array}$ & $8.2(4.8-12.9)$ & $8.4(5.3-12.4)$ \\
\hline $\mathrm{HbA}_{1 c}, \mathrm{mmol} / \mathrm{mol}$ & $50 \pm 0.8^{*}$ & $63 \pm 1.2^{*}$ \\
\hline $\mathrm{HbA}_{1 \mathrm{c}}, \%$ & 6.7 & 8.0 \\
\hline BMI, $\mathrm{kg} / \mathrm{m}^{2}$ & $31.0 \pm 6.2$ & $30.8 \pm 5.6$ \\
\hline $\begin{array}{l}\text { Systolic blood pressure, } \\
\mathrm{mmHg}\end{array}$ & $146.9 \pm 21.1$ & $144.9 \pm 20.7$ \\
\hline Fasting glucose, $\mathrm{mmol} / \mathrm{l}$ & $7.5 \pm 2.1^{*}$ & $8.8 \pm 2.7^{*}$ \\
\hline $\begin{array}{l}\text { Total cholesterol, } \\
\mathrm{mmol} / \mathrm{l}\end{array}$ & $4.6 \pm 1.0$ & $4.6 \pm 1.1$ \\
\hline $\begin{array}{l}\text { HDL cholesterol, } \\
\mathrm{mmol} / 1\end{array}$ & $1.20 \pm 0.3$ & $1.17 \pm 0.3$ \\
\hline Triglycerides, mmol/l & $1.88 \pm 1.5$ & $1.86 \pm 1.1$ \\
\hline Metformin use only, $\%$ & 22.8 & 21.7 \\
\hline Sulphonylurea use only, \% & 15.3 & 14.3 \\
\hline $\begin{array}{l}\text { Metformin }+ \\
\text { sulphonylurea use, \% }\end{array}$ & $40.5^{*}$ & $46.6^{*}$ \\
\hline Other combination use, $\%$ & $6.1^{*}$ & $3.5^{*}$ \\
\hline $\begin{array}{l}\text { Unknown medication } \\
\text { use, } \%\end{array}$ & 15.3 & 13.9 \\
\hline Any retinopathy, $\%$ & 6.8 & 10.6 \\
\hline \multicolumn{3}{|l|}{ Retinopathy, \% } \\
\hline Grade 1 & 3.4 & 6.8 \\
\hline Grade 2 & 0 & 1.7 \\
\hline Grade 3 & 1.1 & 0.9 \\
\hline Grade 4 & 2.3 & 1.2 \\
\hline Microalbuminuria, \% & 24.0 & 27.3 \\
\hline $\begin{array}{l}\text { Glomerular filtration } \\
\text { rate, } \mathrm{ml} / \mathrm{min} / 1.73 \mathrm{~m}^{2}\end{array}$ & $84.7 \pm 33.0$ & $89.6 \pm 33.5^{*}$ \\
\hline $\begin{array}{l}\text { Follow-up duration, } \\
\text { years }\end{array}$ & 5.4 & 5.5 \\
\hline Total mortality, \% & 16.0 & 14.0 \\
\hline
\end{tabular}

Data are mean $\pm S D$, proportions, or median (interquartile range). Between-cluster differences were tested with ANOVA and post hoc Bonferroni for mean levels, with chi-squared tests for proportions and Kruskal-Wal lis test for median levels.

* Statistically significant difference $(P<0.05)$. 